Abstracta Iranicacta Iranica

Revue bibliographique pour le domaine irano-aryen

Volume 22 | 2001

Comptes rendus des publications de 1999

\title{
Beiträge zu altpersischen Inschriften. Wiesbaden, Reichert Verlag, 1999, VII+128 p.
}

\section{Philip Huyse}

\section{Q OpenEdition}

1 Journals

Édition électronique

URL : http://journals.openedition.org/abstractairanica/36190

DOI : 10.4000/abstractairanica.36190

ISSN : 1961-960X

\section{Éditeur :}

CNRS (UMR 7528 Mondes iraniens et indiens), Éditions de l'IFRI

\section{Édition imprimée}

Date de publication : 15 mai 2001

ISSN : 0240-8910

\section{Référence électronique}

Philip Huyse, "Beiträge zu altpersischen Inschriften. Wiesbaden, Reichert Verlag, 1999, VII+128 p. ». Abstracta Iranica [En ligne], Volume 22 | 2001, document 57, mis en ligne le 15 février 2010, consulté le 10 octobre 2020. URL : http://journals.openedition.org/abstractairanica/36190 ; DOI : https://doi.org/ 10.4000/abstractairanica.36190

Ce document a été généré automatiquement le 10 octobre 2020.

Tous droits réservés 


\title{
Beiträge zu altpersischen Inschriften. Wiesbaden, Reichert Verlag, 1999, VII+128 p.
}

\author{
Philip Huyse
}

1 Cinq «contributions aux inscriptions vieux perses» en rapport direct avec une nouvelle édition des inscriptions vieux perses de Naqš-i Rustam et Persépolis, préparée par l'auteur pour le « Corpus Inscriptionum Iranicarum » ont été réunies dans ce mince volume.

2 Le premier article (pp. 1-25) est un commentaire des légendes trilingues accompagnant les figures des trente porteurs du trône sur les reliefs des tombeaux achéménides nos. I à Naqš-i Rustam et $\mathrm{V}$ à Persépolis, pour lesquelles l'auteur propose les nouveaux sigles DNe 1-30 resp. $\mathrm{A}^{3} \mathrm{~Pb}$ 1-30. Le deuxième article (pp. 27-36) concerne quelques remarques en marge des deux inscriptions vieux perses DPd et DPe. Le troisième article (pp. 37-42) est en fait la deuxième partie d'une note portant sur quelques problèmes épigraphiques dans les textes parallèles DNa et XPl (une première partie étant parue dans BAI, 10, 1996 [1998], 15-23, et une troisième dans AMIT 29, 1997, 271-279). Le quatrième article (pp. 43-57) offre un aperçu avec commentaire des inscriptions vieux perses sur des poids datant de l'époque de Darius $\mathrm{I}^{\mathrm{er}}$.

3 Le cinquième et dernier article (pp.59-118) est le plus long et retiendra peut-être le plus l'attention des lecteurs. Les inscriptions achéménides tardives à partir d'Artaxerxès I ${ }^{\text {er }}$ (465-425/4 av. J.-C.) y sont rééditées et la langue vieux perse utilisée dans ces textes y est systématiquement examinée. Les résultats de cet examen permettent d'ailleurs de dater au $4^{\mathrm{e}} \mathrm{s}$. les inscriptions $\mathrm{AmH}$ et $\mathrm{AsH}$, attribuées à Ariaramnès l'arrière-grand-père de Darius I ${ }^{\text {er }}$ et à Arsamès son grand-père. L'hypothèse avancée comme la plus vraisemblable est qu'il s'agit de textes du temps d'Artaxerxès III (359/8-338/7 av. J.-C.). 
INDEX

Thèmes : 2.1. Langues anciennes

\section{AUTEURS}

PHILIP HUYSE

CNRS - Paris 